\title{
PENGARUH HARGA DAN EMOSIONAL TERHADAP KEPUTUSAN PEMBELIAN SABUN LIFEBOY
}

\author{
Hesti Sabrina \\ Dosen Program Studi Manajemen Fakultas Ekonomi dan Bisnis UMA
}

\begin{abstract}
Abstrak
Penelitian ini bertujuan untuk mengetahui pengaruh harga, dan emosional terhadap keputusan pembelian sabun Lifeboy. Populasi dalam penelitian ini adalah mahasiswa FEB UMA angkatan 2016 yang berjumlah 672 mahasiswa, dalam pengambilan sampel dilakukan dengan metode random sampling sehingga dapat ditentukan jumlah sampel sebanyak 87 mahasiswa. Teknik analisa data yang digunakan adalah menggunakan rumus analisis regresi berganda, dengan rumus : $Y=a_{0}+b_{1} x_{1}+$ $b_{2} x_{2}+e$ Dari hasil analisis data maka diperoleh persamaan analisis regresi berganda $Y$ $=3,643+0,325 x_{1}+0,162 x_{2}$. Untuk mengetahui konstribusi variabel bebas terhadap variabel terikat digunakan koefisien determinasi dengan hasil 9,5\%. Hal ini menujukkan bahwa pengaruh harga, dan emosional terhadap keputusan pembelian pada sabun Lifeboy sebesar 9,5\%. Untuk menguji hipotesis digunakan uji signifikansi $\alpha$ sebesar 0,05, dan hipotesis diterima karena signifikansi penelitian $<0,05(0,000<0,05)$. Kemudian hipotesis dapat dibuktikan dengan menggunakan uji $F$ dan uji t yang masing - masing membandingkan tabel dengan nilai $F$ dan $t$ hitung. Dari uji $F$ diperoleh bahwa nilai $F$ hitung $>F$ tabel $(6,918>2,68)$, dengan menggunakan hasil ini dapat dibuat kesimpulan bahwa ada pengaruh simultan variabel bebas terhadap variabel terikat. ttabel digunakan untuk menghitung pengaruh masing-masing variabel bebas terhadap variabel terikat. Nilai t hitung untuk variabel harga adalah 3,150 dan > 1,984 sehingga hipotesis untuk variabel ini diterima. Untuk variabel bebas kedua, emosional telah memperoleh nilai thitung adalah 2,288 >1,984 dan hipotesis diterima.
\end{abstract}

Kata kunci: Harga, Emosional, Keputusan Pembelian

\section{PENDAHULUAN}

Setiap perusahaan akan berusaha untuk saling bersaing untuk memenuhi pangsa pasar sehingga menuntut optimalisasi dalam penciptaan maupun pemasaran produk, serta berbagai strategi untuk mendapatkan konsumen membeli produk yang ditawarkan. Keputusan pembelian merupakan suatu perilaku yang dilakukan oleh individuindividu yang berbeda untuk membeli suatu produk tertentu yang ditawarkan oleh perusahaan atau yang ditemukan di pasar. Pemasar sebagai pihak yang menawarkan berbagai produk kepada konsumen harus dapat menganalisis faktor-faktor yang mempengaruhi konsumen dalam pembelian, mengetahui persepsi konsumen dalam menilai sesuatu yang berpengaruh dalam pembelian sehingga pemasar dapat merancang strategi pemasaran yang sesuai dengan keinginan konsumen.

Ada beberapa faktor yang mempengaruhi keputusan pembelian, diantaranya terkandung dalam bauran pemasaran. Menurut Tjiptono (2000:30) bauran pemasaran adalah seperangkat alat yang dapat digunakan untuk membentuk karakteristik produk yang ditawarkan kepada pelanggan. 
Dalam penelitian ini penulis meneliti satu faktor dari unsur bauran pemasaran yaitu pricing. Karena product, place dan promotion telah dilakukan oleh hampir semua perusahaan konvensional yang relatif sama.

Sabun merupakan jenis produk yang dibutuhkan oleh semua kalangan, baik kalangan ekonomi rendah, menengah, dan tinggi karena setiap orang dituntut untuk tetap bersih dan sehat. Salah satu upaya untuk menjaga tetap bersih dan sehat adalah membersihkan seluruh anggota badan (mandi) secara teratur menggunakan sabun mandi. Dengan semakin tinggi tingkat kesadaran akan kebersihan menjadikan sabun mandi adalah salah satu produk bisnis yang sangat menguntungkan.

Produk sabun mandi sebagai alat pembersih yang sekaligus memperindah kulit, banyak beredar di pasar dengan berbagai ragam merek. Hal itu membuat konsumen semakin kritis dalam memilih produk sabun mandi. Pada industri sabun mandi dikenal ada dua jenis, yaitu sabun mandi biasa dan sabun mandi kesehatan. Sebagai objek penelitian, penulis mengambil Sabun Lifeboy sebagai sabun kesehatan yang diproduksi oleh PT. Unilever Indonesia Tbk.

Pesaing dari Sabun Lifeboy cukup banyak sehingga dibutuhkan suatu strategi untuk meningkatkan keinginan konsumen untuk membeli dan mengkonsumsi produk yang ditawarkan. Para pemasar menerapkan strategi harga bersaing. Sabun Lifeboy dipasarkan dengan harga standar yaitu terjangkau namun juga tidak terkesan murahan.
Selain faktor harga, diduga ada faktor lain yang dapat menarik minat konsumen untuk membeli suatu produk, yaitu faktor emosional. Kaitannya dengan sabun Lifeboy yang memiliki lebih banyak keunggulan yaitu lebih praktis dan lebih banyak membunuh kuman sehingga memberikan kesan bersih di setiap mandi. Keunggulan tersebut diharapkan pemasar dapat menguatkan faktor emosional konsumen dalam membuat keputusan pembelian.

Faktor emosional memiliki pengaruh yang cukup unik dalam keputusan pembelian. Karena emosi merujuk pada suatu perasaan dan pikiran yang khas, suatu keadaan biologis dan psikologis dan serangkaian kecenderungan untuk bertindak baik rangsangan dari luar maupun dari dalam individu (Goleman,2002:411). Sehingga peneliti merasa perlu diadakannya suatu penelitian mengenai pengaruh faktor emosional terhadap keputusan pembelian.

\section{KAJIAN PUSTAKA \\ Harga \\ Pengertian Harga}

Istilah harga tidaklah asing lagi bagi semua orang, namun kemajuan akan ekonomi membuat harga mempunyai istilah lain seperti dalam layanan jasa bank, harga disebut juga dengan bunga dan dalam bisnis akuntansi, periklanan, dan konsultan disebut fee. Harga tercipta biasanya dari adanya tawar-menawar antara para penjual dengan pembeli, setelah tercipta kesepakatan harga.

Harga merupakan satu-satunya unsur dalam bauran pemasaran yang menghasilkan pendapatan sedangkan 
unsur yang lainnya, hanya merupakan unsur biaya saja. Harga mempengaruhi tingkat penjualan, tingkat keuntungan market share yang dapat dicapai oleh perusahaan. Menurut Swastha dan Sukotjo (2000 : 211) "Harga adalah sejumlah uang (ditambah beberapa produk kalau mungkin) yang dibutuhkan untuk mendapatkan sejumlah kombinasi dari produk dan pelayanannya".

\section{Tujuan Penetapan Harga}

Tujuan-tujuan penetapan harga memiliki implikasi penting terhadap strategi bersaing perusahaan. Tujuan yang ditetapkan harus konsisten dengan cara yang ditempuh perusahaan dalam menempatkan posisi relatifnya dalam persaingan. Misalnya, pemilihan tujuan berorientasi pada laba mengandung makna bahwa perusahaan akan mengabaikan harga para pesaing. Pilihan ini cocok ditetapkan dalam tiga kondisi, menurut Tjiptono (2000: 153-154) yaitu :

1. Tidak ada pesaing

2. Perusahaan beroperasi pada kapasitas produksi maksimum

3. Harga bukanlah merupakan atribut yang penting bagi pembeli

\section{Emosional}

\section{Pengertian Emosi}

Kata emosi berasal dari bahasa latin, yaitu emovere, yang berarti bergerak menjauh. Arti kata ini menyiratkan bahwa kecenderungan bertindak merupakan hal mutlak dalam emosi. Menurut Goleman (2002:411) emosi merujuk pada suatu perasaan dan pikiranyang khas, suatu keadaan biologis dan psikologis dan serangkaian kecenderungan untuk bertindak. Emosi pada dasarnya adalah dorongan untuk bertindak. Biasanya emosi merupakan reaksi terhadap rangsangandari luar dan dalam diri individu. Sebagai contoh emosi gembira mendorong perubahan suasana hati seseorang, sehingga secara fisiologi terlihat tertawa, emosi sedih mendorong seseorang berperilaku menangis.

\section{Faktor-faktor yang Mempengaruhi Emosional}

Menurut Astuti (2005), beberapa ahli psikologi menyebutkan adanya beberapa faktor yang mempengaruhi perkembangan emosi seseorang yaitu:

1. Pola asuh orang tua

2. Pengalaman traumatik

3. Temperamen

4. Jenis Kelamin

5. Usia

6. Perubahan Jasmani

7. Perubahan Interaksi dengan Teman Sebaya

8. Perubahan Pandangan Luar

9. Perubahan Interaksi dengan Sekolah

\section{Keputusan Pembelian}

Keputusan pembelian adalah tindakan yang dilkukan konsumen dalam upaya memecahkan masalah dalam pemenuhan kebutuhan. Sebelum memutuskan untuk melakukan pembelian, konsumen sering dihadapkan pada pilihan/alternative yang beragam. Hal ini wajar mengingat banyaknya jumlah produk maupun jasa yang berada di pasaran dengan fungsi dan manfaatnya masing-masing. Pengambilan keputusan pembelian juga dipengaruhi oleh situasi dimana proses dan perilaku beli terjadi. Situasi komunikasi, situasi 
pembelian, situasi penggunaan, dan situasi penyingkiran produk semuanya mempengaruhi keputusan pembelian.

Simamora

(2001:13)

mendefinisikan

:'Pengambilan

keputusan adalah proses-proses yang terdiri dari tahap-tahap pengenalan masalah, pencarian informasi, evaluasi alternaif, pembelian dan perilaku konsumen".

\section{METODE PENELITIAN}

Penelitian ini dilakukan di Fakultas Ekonomi dan Bisnis UMA Jalan Setia Budi 79 B/Jl. Sei Serayu No. 70 A Medan. Populasi dalam penelitian adalah Mahasiswa FEB UMA angkatan 2016 yang berjumlah 672 mahasiswa. Sampel dalam penelitian ini berjumlah 87 mahasiswa dengan taraf kesalahan $10 \%$. Teknik analisa data yang digunakan untuk mengetahui seberapa besar pengaruh pengaruh harga dan emosional terhadap keputusan pembelian, maka digunakan rumus regresi linear berganda (Multiple Regression) (Umar, 2002:174).

\section{HASIL PENELITIAN PEMBAHASAN \\ Hasil Penelitian \\ Analisis Regresi Berganda}

Dalam penelitian ini model yang digunakan adalah model regresi berganda dengan formula sebagai berikut :

$$
\mathrm{Y}=\mathrm{a}+b_{1} x_{1}+b_{2} x_{2}+\mathrm{e}
$$

Maka, dengan melihat angka-angka pada hasil SPSS diperoleh persamaan regresi berganda seperti di bawah ini. $\mathrm{Y}=3,643+0,325 x_{1}+0,162 x_{2}+\mathrm{e}$

1. Jika harga dan emosional konstan (nol), maka keputusan pembelian akan sebesar nilai konstanta sebesar 3.643 .

2. Jika harga meningkat sebesar satu satuan, maka keputusan pembelian akan meningkat sebesar 0.325 satuan.

3. Jika emosional meningkat sebesar satu satuan, maka keputusan pembelian akan meningkat sebesar 0.162 satuan.

\section{Uji t}

Pengujian hipotesis dilakukan dengan cara membandingkan besarnya angka taraf signifikansi (sig) penelitian dengan taraf signifikansi sebesar 0,05 dengan kriteria sebagai berikut: Hipotesis diterima jika sig penelitian $<0,05$, dan hipotesis ditolak jika sig penelitian $>0,05$. Berdasarkan tabel Coefficient, diperolah Sig penelitian sebesar 0,002 . Dengan demikian hipotesis diterima. Artinya, harga memiliki pengaruh positif dan signifikan terhadap keputusan pembelian. Pada tabel Coefficient (nilai t) harga adalah sebesar 3,150, dengan membandingkan nilai t hitung dengan nilai $\mathrm{t}$ tabel pada degree of freedom $=$ $\mathrm{n}-\mathrm{k}$, maka $\mathrm{DF}=269-3=266$, nilai $\mathrm{t}$ tabel pada $\mathrm{DF}=3$ adalah 1,984. Maka dengan demikian hipotesis diterima dengan membandingkan nilai $t$ hitung dengan $t$ tabel. Dimana syarat hipotesis diterima adalah jika $t$ hitung $>\mathrm{t}$ tabel.

Pengujian hipotesis dilakukan dengan cara membandingkan besarnya angka taraf signifikansi (sig) penelitian dengan taraf signifikansi sebesar 0,05 dengan kriteria sebagai berikut:Hipotesis diterima jika sig penelitian $<0,05$, dan hipotesis ditolak jika sig penelitian $>0,05$. Berdasarkan tabel Coefficient, 
diperolah Sig penelitian sebesar 0,023 . Dengan demikian hipotesis ditolak. Artinya, emosional memiliki pengaruh positif dan signifikan terhadap keputusan pembelian. Pada tabel Coefficient (nilai t) emosional adalah sebesar 2,288, dengan membandingkan nilai t hitung dengan nilai $t$ tabel pada degree of freedom $=$ $\mathrm{n}-\mathrm{k}$, maka $\mathrm{DF}=269-3=266$, nilai $\mathrm{t}$ tabel pada $\mathrm{DF}=3$ adalah 1,984 . Maka dengan demikian hipotesis diterima dengan membandingkan nilai t hitung dengan $t$ tabel. Dimana syarat hipotesis diterima adalah jika $t$ hitung $>\mathrm{t}$ tabel.

\section{Uji F}

Berdasarkan hasil SPSS diperoleh angka signifikansi penelitian (Sig penelitian) yang diperoleh dari hasil perhitungan adalah sebesar 0,000 . Dengan demikian angka Sig penelitian $<0,05$, maka hipotesis diterima. Artinya, ada pengaruh yang positif dan signifikan antara harga dan emosional terhadap keputusan pembelian.

Hipotesis juga dapat di uji dengan membandingkan nilai $\mathrm{F}$ tabel dengan $\mathrm{F}$ hitung yang diperoleh dari tabel Anova di atas. Hipotesis diterima jika $\mathrm{F}$ hitung $>\mathrm{F}$ tabel, $\mathrm{F}$ tabel ditentukan dengan mencari terlebih dahulu menentukan derajat kebebasannya dengan cara $d f=\mathrm{n}-\mathrm{k}$, dimana $\mathrm{k}$ adalah variabel bebas. $D f=$ $269-3=266$, nilai $\mathrm{F}$ tabel untuk $d f=$ 266 adalah sebesar 2,68 , sementara $\mathrm{F}$ hitung sebesar 6,918. F Hitung $>$ F tabel $(6,918>2,68)$. Sehingga dengan hal ini hipotesis diterima.

\section{Uji Koefisien Determinasi ( $\left.\mathbf{R}^{\mathbf{2}}\right)$}

Besarnya nilai $R$ Square $\left(\mathrm{R}^{2}\right)$ adalah 0,095. Angka tersebut dapat digunakan untuk melihat besarnya pengaruh harga dan emosional terhadap keputusan pembelian dengan menghitung Koefisien Determinasi (KD). Nilai KD sebesar $9.5 \%\left(\mathrm{r}^{2} \mathrm{x}\right.$ $100 \%)$ memiliki arti bahwa pengaruh harga dan emosional secara gabungan terhadap keputusan pembelian adalah sebesar 9,5\%. Adapun sisanya sebesar 90,5\% (100\%-9,5\%) dipengaruhi oleh faktor lain. Dengan kata lain, besarnya variabel keputusan pembelian yang dapat diterangkan dengan menggunakan variabel harga dan emosional adalah sebesar 9,5\%, sedangkan pengaruh sebesar 90,5\% disebabkan oleh variabel lain di luar penelitian ini.

\section{Pembahasan Penelitian}

Dari analisis yang dilakukan, harga memiliki pengaruh yang positif dan signifikan terhadap keputusan pembelian yaitu sebesar 0.325 . Artinya jika harga yang diberikan dan yang tersedia meningkat 1 satuan, maka keputusan pembelian akan meningkat sebesar 0.325 . Berdasarkan teori hal ini dapat diterima, dimana pada umumnya jika perusahaan memberikan harga yang kompetitif dan efektif, maka perusahaan akan mendapatkan keuntungan yang lebih tinggi lagi melalui tingkat penawaran yang terjadi. Harga juga biasanya dibarengi dengan penawaran tingkat potongan yang diberikan kepada calon pelanggan. Hal ini secara otomatis akan meningkatkan kegairahan pelanggan untuk melakukan transaksi pembelian. Dari penelitian yang telah dilakukan, diketahui bahwa pengaruh emosional terhadap keputusan pembelian yaitu sebesar 0.162 . Dalam analisisnya, variabel emosional 
memiliki signifikansi dan bernilai positif. Artinya, jika harga meningkat 1 satuan, maka tingkat keputusan pembelian juga akan meningkat sebesar 0,162 satuan.

\section{PENUTUP}

Dari penelitian dan pengolahan data yang telah dilakukan, ditemukan bahwa:

1. Variabel harga berpengaruh terhadap keputusan pembelian sebesar 0.325. Variabel ini memberikan kontribusi yang lebih besar terhadap keputusan pembelian, mengingat harga adalah hal yang urgent untuk dijaga oleh perusahaan.

2. Variabel emosional berpengaruh terhadap keputusan pembelian sebesar 0,162. emosional juga memiliki peran yang positif dalam meningkatkan keputusan pembelian, dalam hal ini keputusan pembelian mengacu pada tingkat emosional yang sesuai dengan kemampuan calon pembeli. Emosional pembeli harus diperhatikan oleh perusahaan untuk meningkatakan keputusan pembelian

\section{DAFTAR PUSTAKA}

Amir, M. Taufiq. 2005. Dinamika Pemasaran. Jakarta : PT. Rajagrafindo Persada.

Armstrong, Kotler. 2001. Prinsipprinsip pemasaran. Edisi Kedelapan jilid I. Jakarta : Erlangga

Astuti. 2005. Faktor-faktor yang Mempengaruhi Perkembangan Emosi Peserta Didik. http://wawanjunaidi.blogspot.com.
Gitosudarmo, Indriyo. 2000. Manajemen Pemasaran, Edisi I, Yogyakarta : BPFE - UGM.

Kismono. 2001. Pengantar Bisnis. Yogyakarta : BPFE.

Kotler. 2001. Manajemen Pemasaran di Indonesia, Analisis, Perencanaan, Implementasi dan Pengendalian. Edisi Pertama jilid I. Jakarta. Penerbit Salemba Empat. Dan Armstrong. 2002. Manajemen Pemasaran. Jakarta : Prehalindo Kuncoro. Dan A. B. Susanto, 2001. Manajemen Pemasaran di Indonesia. Buku 2, Jakarta : Salemba Empat.

Mowen, Jhon $\mathrm{C}$ dan Michael Miror. 2002. Perilaku Konsumen. Jakarta : Erlangga

Peter dan Olson. 2000. Consumer Behaviour. Edisi 4, Jilid 2. Jakarta: Erlangga 2002.

Consumer Behavior. edisi 6. McGraw Hill. New York.

Prasetijo, Ristiyanti dan Jhon. 2004. Perilaku Konsumen. Yogyakarta : Andi

Rambat, Lupiyoadi. 2001. Manajemen Pemasaran Jasa Teori dan Praktik. Jakarta : Salemba Empat

Riduwan. 2009. Metode dan Teknik Menyusun Tesis. Bandung: Penerbit Alfabeta

Saladin. 2008. Pengertian Harga. http://one.indoskripsi.com.

Setia Budi, Avi. 2008. Definisi Persepsi. http://id.shvoong.com/socialsciences/psychology/1837978

Setiadi. 2003. Perilaku Konsumen dan Implikasi untuk Strategi dan Penelitian Pemasaran. 
JURNAL PLANS

Penelitian Ilmu Manajemen \& Bisnis

ISSN: $1978-7057$

E-ISSN: 2527-306X

Cetakan Pertama. Jakarta : Prenada Media

Simamora, Bilson. 2001, Memenangkan Pasar dengan Pemasaran Efektif dan Profitabel. Jakarta : Gramedia Pustaka Utama.

Sumarsono. 2004. Metode Riset Sumber Daya Manusia. Yogyakarta: Graha Ilmu

Swastha, Basu. 2000. Azas-Azas Marketing. Yogyakarta : Liberty dan Sukotjo. 2000.

Manajemen Pemasaran

Modern. Yogyakarta: Liberty

Tjiptono. Fandy.2000. Strategi

Pemasaran. Edisi Kedua.

Cetakan Keempat.

Yogyakarta: Penerbit. .2006. Service, Quality, \& Satisfication. Yogyakarta: Penerbit Andi

Umar, Husein.2005. Metode Penelitian Untuk Skripsi dan Tesis Bisnis. Jakarta: PT Raja Grafindo. 